\title{
REVITALIZING NATIONAL POLITICAL VALUES THROUGH THE SOCIO-POLITICAL MOVEMENTS OF THE TAREKAT: \\ Studied at the Political Social Role of Tarekat Qadiriyah wa Naqsyabandiyah in Nusantara
}

\author{
Amir Maliki Abitolkha, Muhamad Basyrul Muvid and \\ Maulana Arafat Lubis
}

Universitas Islam Negeri Sunan Ampel Surabaya,

Jawa Timur, Indonesia

Universitas Dinamika Surabaya, Jawa Timur, Indonesia

Institut Agama Islam Negeri Padangsidimpuan,

Sumatera Utara, Indonesia

email: amir.abitolkha@gmail.com,muvid@dinamika.ac.id, maulanaarafat62@gmail.com

Abstract: The tarekat is not only understood as a spiritual-religious organization, but also a socio-political organization capable of contributing to the nation's sovereignty and independence. This research aims to find and analyze the process of revitalizing the national political values of the Qadiriyahwa Naqsyabandiyah order. The method used is studying literature by digging into various references, documentation, and journals that correspond to the topic. From the literature, it was found that the Qadiriyahwa Naqsyabandiyah tarekat successfully played its socio-political role to help the People and People of Indonesia get out of the difficulties, sufferings, and tribulations of colonialism. Because its role as social jam'iyah is minimal, so tarekat extends to the religio-political aspect. Then, the process of revitalizing the national political values of the Qadiriyah wa Naqsyabandiyah order can be seen from several steps: through the role of the elite of the order, through the religiopolitical system, relations with political parties, through the synergy between the encouragement of Islamic teachings, the motivation of individuals and groups, and interaction with the outside world, through the function of the order as a religious and social institution. 
الملخص: ولا يُفهم الأمر على أنه منظمة دينية روحية فحسب، بل هو منظمة اجتماعية

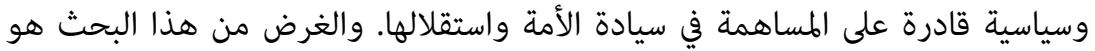

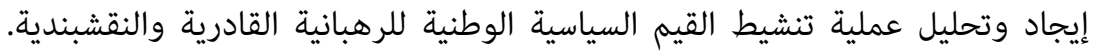

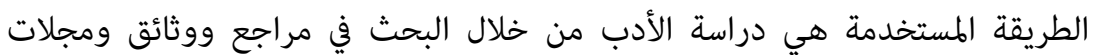

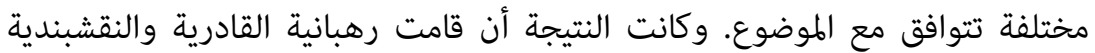

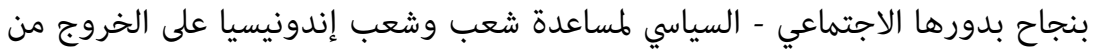

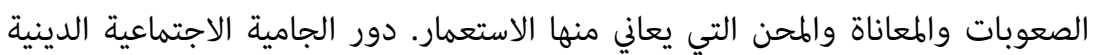

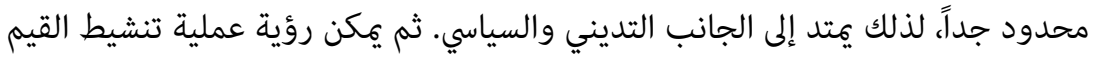

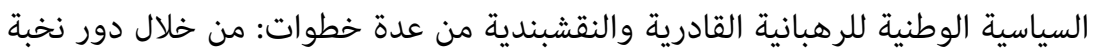

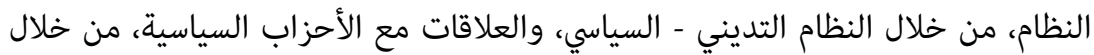

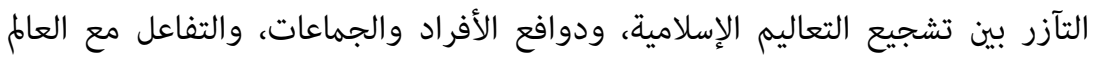
الخارجي، من خلال وظيفة النظام كمؤسسة دينية واجتماعية.

Abstrak: Tarekat tidak hanya dipahami sebagai organisasi keagamaan spiritual, semata, namunia sebagai organisasi social politik yang mampu memberikan kontribusi terhadap kedaulatan dan kemerdekaan bangsa. Tujuan penelitian ini ingin menemukan dan menganalisis proses revitalisasi nilai-nilai politik kebangsaan tarekat Qadiriyah wa Naqsyabandiyah. Metode yang digunakan adalah studi kepustakaan dengan menggali berbagai referensi, dokumentasi, dan jurnal-jurnal yang sesuai dengan topik. Hasil yang ditemukan adalah Tarekat Qadiriyah wa Naqsyabandiyah berhasil memainkan peran sosial politiknya untuk membantu masyarakat dan bangsa Indonesia keluar dari kesulitan, penderitaan dan kesengsaraan akibat penjajahan. Peran sebagai jam'iyah sosial keagamaan sangat terbatas, sehingga diperluas kepada aspek religio-politik. Kemudian, proses revitalisasi nilainilai politik kebangsaan tarekat Qadiriyah wa Naqsyabandiyah dapat dilihat dari beberapa langkah: melalui peranan elit tarekat, melalui sistem religio-politik, relasi dengan partai politik, melalui sinergitas antara dorongan ajaran Islam, motivasi individu dan kelompok, dan interaksi dengan dunia luar, melalui fungsi tarekat sebagai lembaga keagamaan dan sosial.

Keywords: tarekat, mursyid, movement, social-politics, nation. 


\section{INTRODUCTION}

The tarekat represents Sufistic teaching that is oriented towards the realm of the spiritual amaliah that Murshid can do. The spiritual amaliah is a field to improve the soul, calm the mind, cleanse the heart, and draw Allah Swt. closer. The tarekat of the religious activities that have experienced the success of his time that attracts various circles, so that the congregation's organization can be used as a social-political force, in addition to religious coercion. The order's social-political effect became a dominant force caused by the Murshid (charismatic) and large membership. ${ }^{1}$

The tarekat does not focus on the problem 'ubudiyah merely by spending the whole time praying to Allah Swt. However, the tarekat became a"muharrik" in the affairs of the nation and the state, and it becomes a powerful weapon to safeguard the sovereignty of the nation and state. Thus, it is appropriate to say Sufism as the national movement. It expands the meaning and function of Sufism following the dynamics of ever-changing times. It means Sufism is not static, but dynamic and flexible according to the times' conditions and demands. The national movement has a high nationalism meaning, given that its managed to actualize the values of Islamic teachings into real life through the "jihad" movement of the nationality, namely the effort to defend the honour, sovereignty, and benefit of the people from the shackles of invaders, colonialism and slavery that are not fairies of humanity and fairy justice. The term nationalist Sufi shows balance between world affairs and the hereafter, the individual and the social, and spiritual and national issues.

Bruinessen and Howell strengthen the above explanation. ${ }^{2}$ According to them, people practicing Sufism expressed a new political

1 J. Spencer Trimingham, The Sufi Order in Islami (New York: Oxford University Press, 1973), 3.; George Ritzer and Douglas J. Goodman, Teori Sosilogi Modern, terj. Alimandan, (Jakarta: Prenada Media, 2005), 51.;Agus Riyadi, "Tarekat Sebagai Organisasi Tasawuf," Jurnal at Taqaddum 6, no. 2 (2014): 361.;Syawaluddin Nasution, "Negara Dan Nasionalisme Dalam Pandangan Kaum Tarekat (Studi Terhadap Tarekat Naqsyabandiyah Khalidiyah Babussalam)" (Universitas Islam Negeri Sumatera Utara, 2018), 75-78 dan 253-66.; Muhammad Basyrul Muvid and Nur Kholis, "Konsep Tarekat Sammaniyah Dan Peranannya Terhadap Pembentukan Moral, Spiritual Dan Sosial Masyrakat Post Modern," Dialogia: Jurnal Studi Islam Dan Sosial 18, no. 1 (2020): 79-99, https://doi.org/10.21154/dialogia.v18i1.2038.

2 Bruinessen and Howell, Sufisme and the 'Modern' in Islam (New York: I.B. Tauris \& Co. Ltd, 2007), 10.; Dudung Abdurrahman, "Diversity of Tarekat Communities 
role as a pioneer of the modern nationalist movement. It can be found in movement waves in the jihad movement led by Sufi against the colonial rule or the late 19th and early 20th-century indigenous elites. For example, the Sanusiyah order has given a structure that integrates to the fragmented of the Bedouin tribe of Cyrenaica to play a role indevelopingthe Libyan nation.

Another case could also be seen during major jihadi events in the early nineteenth century in northern Nigeria, led by Usman and Fodio, a follower of the tarekat Qadiriyah. In many other areas, Sufism is associated with reform movements and jihad campaigns against the invaders. In the 19th and 20th centuries, many Sufi traditions were directly or indirectly involved in mobilizing a Muslim response to the Western world. Thus, they were prepared for the resistance movement against foreign powers, especially in the 19th century. Many wars initiated $t$ by the European forces were challenged by Muslim organizations with Sufi origins. ${ }^{3}$

The national dimension is hand in hand with politics. The Sufi order (tarekat) shows it's nationality's political role as a modern nationalist movement pioneer. In the political aspect, Sufism provides a structure that integrates the community, becomes a fortress of ethnic and nationalistic legislative mobilization instruments, and appears as a reform movement and a Jihad campaign against the (west) invaders. Thus, Sufism provides an organizational framework and an intellectual inspiration for modern challenges for Islam, particularly foreign powers. ${ }^{4}$

In addition to the national movement, the order also took a role as the struggle movement that drove it into a Sufistic militancy movement in the context of the colonial, and the contemporary era,

and Social Changes in Indonesian History," Sunan Kalijaga: International Journal of Islamic Civitization 1, no. 1 (2018): 61-92, https://doi.org/https://doi.org/10.14421/ skijic.v1i1.1217.

3 Rabi'ah Nasir and Arsheed Ahmad Malik, "Role and Importance of Sufism in Modern World," International Journal of Advancements in Research and Technology 2, no. 1 (2013): 8.; Paul Stange, "The Sumarah Movement in Javanesa Mysticism" (University Wiconsin-Madison, 1980).; E.E. Evan-Pritchard, The Sanusi of Cyrenaica (London: Oxford University Press, 1949).; Nicola A. Ziadeh and Sanusiyah, A Studi of a Revivalist Movement in Islam (Leiden: Brill, 1958).

4 Sokhi Huda, "Karakter Historis Sufisme: Masa Klasik, Modern Dan Kontemporer," Teosofi: Jurnal Tasawuf Dan Pemikiran Islam 7, no. 1 (2017): 81, https://doi.org/https://doi.org/10.15642/teosofi.2017.7.1.30-63. 
militancy increased sharply so that it contrasted with the general attribution of the (Sufi) people who are peaceful, loving, tolerant and inclusive. To explain the emergence of the unusual militancy of the Sufi orders in the colonial period, the most prominent scholars are Fazlur Rahman who introduced the concept of 'neo-Sufism'. This concept brought several notable changes in Sufism during the late 18th and early 19th centuries. Neo-Sufism emphasizes internal criticism of Sufism with the source of Islamic teachings and the modern world's challenges. ${ }^{5}$

The Sufi struggle movement became an indicator of neo-Sufism, a significant concern for the nation's problems and social society. It was not concerned with the political issues, but it attempted to play a role in maintaining the nation's political stability so that human life can normally run, healthy, and be peaceful and prosperous that will affect peace in prayer, work, society, congregation, and others. Thus, this delivers them (the Sufi order; Sufism) to be a people who can adapt well, making a breakthrough socio-political with the great made through the struggle and cooperation with various parties to safeguard the state's sovereignty from the colonial elements (invaders).

The Qadiriyah wa Naqsyabandiyah also practices it in the era of Shaikh Abdul Karim al Bantani; he became an intellectual leader behind the movement of the Banten community protest against the Dutch in 1888 A.D. during his position as a murshid caliph of Qadiriyah wa Naqsyabandiyah at that time. ${ }^{6}$ In the 20 th century, A.D. Qadiriyah wa Naqsyabandiyah in Nusantara played a more aggressive role under KH Mustain Ramliy by joining directly to the political stage giving its support to the Golkar party in the early decades of 1970. At the time, Golkar was the ruling party. This controversy is the highlight of the internal order of Qadiriyah wa Naqsyabandiyah.

5 Nasir and Malik, "Role and Importance of Sufism in Modern World," 8.; Ja'far, "Tarekat Dan Gerakan Sosial Keagamaan Syakh Hasan Maksum," Teosofi: Jurnal Tasawuf Dan Pemikiran Islam 5, no. 2 (2015): 269-93, https://doi.org/https://doi. org/10.15642/teosofi.2015.5.2.269-293.; Abdul Qudus and Lalu Muhammad Ariadi, "Gerakan Tarekat Dan Pertumbuhan Budaya Berfolosofi Di Lombok," Teosofi: Jurnal Tasawuf Dan Pemikiran Islam 5, no. 2 (2015): 321-45, https://doi.org/https://doi. org/10.15642/teosofi.2015.5.2.321-345.

6 Sartono Kartodirejo, The Peason Revolt of Banten in 1888 ('S Gravenhage: Nijhoff, 1966); Muhsin Jamil, Tarekat Dan Dinamika Sosial Politik (Yogyakarta: Pustaka Pelajar, 2005), 84-85. 
Kyai Muhamad Shiddiq Kudus as a practitioner and Badal caliph of the Qadiriyah wa Naqsyabandiyah order of Rejoso Jombang is also well known as a politician Kyai due to his involvment in political parties. He believes that being active in politics through political parties is a way to preach Islam and amar ma'ruf nahi mungkar is legitimate. He is also known as an integrative kiyai tarekat, which positions religion and politics closely or integrates spiritual power with political power. ${ }^{7}$ Later, al-Abza's study, et al. also mentioned that the Qadiriyah wa Naqsyabandiyah order, especially in Cukir Jombang, did not prohibit its members from being closely associated with the political world and political parties. His mursyids had a good relationship with the officials of political parties, the United Development Party (PPP). This strong relationship makes the order have strong positions in support of certain political parties and powers. ${ }^{8}$

Based on the above studies have not been found how to build national political values and the process in the view of the Qadiriyah wa Naqsyabandiyah tarekat. Therefore, additional in-depth research is needed to analyze and find the process of revitalizing national political values through the socio-political movement of the Qadiriyah wa Naqsyabandiyah tarekat.

\section{THE ROLE OF SOCIO-POLITICAL AFFAIRS OF QADIRIYAH WA NAQSAYABANDIYAH IN NUSANTARA}

Qadiriyah wa Naqsyabandiyah is a joint Sufi order (tarekat) between the tarekat Qadiriyah which was established by Shaykh Abdul Qadir al-Jilani (470-561 H/1077-1166 AD) and the tarekat Naqsyabandiyah, which was founded by Muhammad bin Baha al-Din al-Uwaisi alBukhari (717-791 H/1318-1389 M) by Indonesian scholars namely Shaikh Ahmad Khatib al-Sambas of West Kalimantan (1217-1289

7 Ma'mun Mu'min, "PergumulanTarekat dan Politik: Peranan Kiyai Haji Muhammad Shiddiq dalam Tarekat dan Politik di Kudus", Fikrah, Vol. 2, No. 1 (Juni 20014), 176-177.; Ali Maschan Moesa, "Kiyai Berpolitik Tidak Dilarang", dalam Aula, No. 03, (Maret 2007), 32-33.; Abdurrahman, "Fenomena Kyai dalam Dinamika Politik: Antara Gerakan Moral danPolitik", Jurnal KARSA, Vol. XV, No. 1 (April 2009), 28.

${ }^{8}$ M. Thohar al-Abza, et.al, "Power Relation Between Tarekat Qadiriyahwa Naqsyabandiyah (TarekatCukir) and Partai Persatuan Pembangunan (PPP) in Jombang, East Java", Episteme, Vol. 14, No. 2 (Desember 2019), 286. 
H/1803-1872 M). The instruction manual on the practice of this order is the book of Fath al-Arifin. This book was written by Shaikh Ahmad Khatib himself and compiled by his students, namely Ma'ruf al-Palimbani, and another manuscript authored by his other students, the Abdur Rahim al-Bali (Muslim student who came from Bali). Qadiriyah wa Naqsyabandiyah has the largerst followers in Indonesia. The centre is in Pesantren Suryalaya Tasikmalaya West Java, in Pesantren Mranggeng Demak Central Java, and in Pesantren Rejoso Jombang East Java. The development of TQN (Tarekat Qadiriyah wa Naqsyabandiyah) did not escape the role of the three caliphs Shaykh Khatib Sambas who made TQN reached the peak of success in Java (in particular) namely West Java (Suryalaya Tasikmalaya), Central Java (Mranggeng Demak) and East Java (Fradian Jombang). The three of them are Shaykh Abdul Karim Banten, Syaikh M. Tholhah Cirebon and Shaykh Ahmad Hasbu al Maduri. ${ }^{9}$

The teachings of this order are most prominent among them is his $d h i k r$ (remembering God). Dhikr in the tarekat of Qadariyah wa Naqsyabandiyah includes the dhikr jahr and dhikr khafi. Dhikr jahr is saying the La IlahaIlla Allah with a loud voice. At the same time, the dhikr khafi (silent remembrance) is reading the word "Allah... Allah" in the heart continually. The practice of dhikr jahr is recited 165 times following each five-time daily prayer. But if the situation is not possible, such as in the journey, sick and so, the dhikr jahr is quite pronounced three times. As for the dhikr khafi, it can be done at any time. The implementation of dhikr jahr and dhikr khafi was intended to strengthen the belief and faith further and finally do occult relationship with the lord of hosts Allah Swt. ${ }^{10}$ The disciples must order when dhikr presenting his teacher's face, Murshid (tawajjuh)

9 Kharisuddin Aqib, Al Hikmah: Memahami Teosofi Tarekat Qadiriyah wa Naqsyabandiyah (Surabaya: Bina Ilmu, 2012), 124.; Ismail Nawawi, Tarekat Qadiriyah Wa Naqsyabandiyah (Surabaya: Karya Agung, 2008), 48.Martin Van Bruinessen, Tarekat Naqsyabandiyah Di Indonesia (Bandung: Mizan Pustaka, 1992), 90-91.; Zamakhsyari Dhofier, Tradisi Pesantren: Studi Tentang Pandangan Hidup Kiyai (Jakarta: LP3ES, 1984), 85-90.; Ali Mashar, "Genealogi Dan Penyebaran Thariqah Qadiriyah Wa Naqshabandiyah Di Jawa," Al-A'raf: Jurnal Pemikiran Islam Dan Filsafat 13, no. 2 (2016): 233-62, https://doi.org/10.22515/ajpif.v13i2.75.

${ }^{10}$ Harun Nasution, Tarekat Qadiriyah Wa Naqsyabandiyah (Tasikmalaya: IAILM, 1990), 220.; Muhammad Basyrul Muvid, "Nilai-Nilai Pendidikan Karakter Dalam Praktik Tarekat Qadiriyah Wa Naqsyabandiyah Di Pondok Pesantren Al Ittihad Tawangsari Trowulan Mojokerto" (UIN Sunan Ampel Surabaya, 2015), 113- 
as a wasilah that continues to connect (genealogy) to the prophet Muhammad and Allah Swt. ${ }^{11}$

Then, the most important event in the tarekat of QadiriyahwaNaqsyabandiyah (TQN) is a monthly and annual "manaqiban" which commemorates the death of Shaikh Abdul Qadir al-Jilani, who died in 11 Rabi' al-Thani where today is the culmination of the celebration. However, there is still a celebration on the 11th of each month. The Murshid was visited by his disciples, including many of them who lived to be present in the warning. In the event before this "sewelasan", a dhikr congregation followed by a reading of manaqib Shaykh Abdul Qadir al-Jilani, which contains a classic story about the life and wonders of the al Jilani behaviour. In TQN, there is no special celebration for Shaykh Baha'uddin a Naqsyabandi, who again shows that the Qadiriyah element in TQN is more dominant. ${ }^{12}$

Apart from the historical aspects and teachings of TQN above, it is necessary to understand that this order has a fundamental role in the struggle against the Netherlands' colonial occupation until independence now. TQN is one of the most massive orders in the archipelago, and it plays a crucial role in maintaining the political stability of Indonesia. It becomes evident that TQN is not only a spiritual jam'iyah, but also a socio-political and education. ${ }^{13}$ Therefore, the order became a unity adhesive movement that participated in the struggle that preach the love of the homeland. Through the unity of the people, will be more able to maintain people's strength, sovereignty, and independence. With this unity, this Indonesian nation, in particular, can achieve freedom.

The resistance that occurred in Banten consisting of farmers, general rural people, and religious figures can not be separated from the background of the TQN movement that time was dominant in

18.; Martin Van Bruinessen, Kitab Kuning, Pesantren Dan Tarekat (Bandung: Mizan Pustaka, 1995), 265.

${ }^{11}$ Abdurrahman Al-Wakil, Hadzihi Hiya Ash-Shufyyah (Beirut: Daar al-Kutub al-Ilmiyah, 1984), 143.

${ }^{12}$ Bruinessen, Tarekat Naqsyabandiyah Di Indonesia, 97.; Nawawi, Tarekat Qadiriyah Wa Naqsyabandiyah, 158-170.

${ }^{13}$ Ulya Fuhaidah, "Tariqa and Philantrophy: The Studi of Tariqa Qadiriyah Naqsyabandiyah Movement in Kuala Tungkal, Jambi," Insaniyat: Journal of Islam and Humanities 3, no. 1 (2018): 29-46, https://doi.org/10.15408/insaniyat.v3i1.7509. 
Banten, and at that time, many culprits were recorded as part of the followers of TQN. In such resistance, TQN provides a network to facilitate communication between the regions and mobilization and to provide its spiritual techniques that are believed to provide strength; magical protection. ${ }^{14}$ The history records that TQN contributed significantly to the Banten peasant Resistance movement in 1888 , K.H. Abdul Karim al Bantani as Murshid TQN through his chronicle of the Khalifa in Banten Haji Marzuki, Haji Wasit, K.H. Tubagus Ismail, Haji Abdul Ghani, and Haji Usman. ${ }^{15}$ In short, TQN became an organization of the feared the dutch army at the time.

The role of TQN which in the mid-19th century was more to the formation of religious and social structures in rural areas of Java. Meanwhile, political, economic, and military domination was in the hands of the Dutch colonialism who wore on to the people's lives and damaged the traditional order of life established previously. For that, TQN expanded its role and function in the political-religious system to confront colonial domination in the island of Java TQN became a transformative movement from the religious, social structure to the political-religion system to benefit and maintain the integrity of the system and the social values that have been well established by the Moslem community before. This kind of change is referred to as "social evolution to the improvement of adapters," which was initially "akhirat centrist" which now transforms the pattern as "political centric."16

The events and paradigms were as a barometer of TQN as an adhesive movement of unity, nationality, and struggle, and religious, spiritual changes how the congregation synergizes the spiritual, social, and state values into a unified integration to deliver a whole society, fairness, mutual tolerance, respect, and love one another. The Sufi order also served as the agent of peace, mediators amid the

${ }^{14}$ Hamidah Hamidah, "Gerakan Petani Banten: Studi Tentang Konfigurasi Sufisme Awal Abad Xix,” Ulumuna 14, no. 2 (November 5, 2017): 333, https://doi. org/10.20414/ujis.v14i2.220.; Kartodirejo, The Peason Revolt of Banten in 1888, 25.

${ }^{15}$ Bruinessen, Kitab Kuning, Pesantren Dan Tarekat, 25.; Jamil, Tarekat Dan Dinamika Sosial Politik, 84.; Dudung Abdurrahman and Syaifan Nur, Sufisme Nusantara: Sejarah Pemikiran Dan Gerakan (Yogyakarta: Ombak, 2019), 58.

${ }^{16}$ Aji Thohir, Gerakan Politik Kaum Tarekat: Telaah Historis Gerakan Politik Antikolonialisme Tarekat Qadiriyah Wa Naqsyabandiyah Di Pulau Jawa (Bandung: Pustaka Hidayah, 2002), 146-147.; K.J. Verger, Realitas Sosial (Jakarta: Gramedia, 1986), 202-208. 
turmoil of society, so that they (the Sufi people) are able to minimize divisions, hostilities, and other problems. Coolness, tenderness, and beauty of the language, speech-backed behavior, make many investigators get sympathizers from various social elements so that they are readily accepted. The kindness and grace of the Sufi words became "dope" (bidders) from divisions, hostilities, conflicts, and disputes. This glorious attitude becomes the capital of the Sufi people to spread compassion for all mankind so that his advice is much heard and accepted by society. The example emitted by the Sufi becomes a barometer of himself as a spiritual teacher whose task is to prosecute humanity into the right path, becoming a pearson who always cultivates compassion for others, and thus prevent conflict and create harmony wihtin the society. Therefore, Sufism deserves to be an adhesive of unity and integrity of society, nation, and state.

Sufism's socio-political movements in the 20th century were distinct from their previous actions, especially in the 19th century. In that century, the movement often appeared in the people's resistance through physical rebellion against the Western colonialism. ${ }^{17}$ Thus, at the beginning of the 20th century, their anti-colonial resistance rarely trigger radical movements. The movement of the people in the century was demonstrated by resistance to the dutch government and the Japanese occupation in the form of strengthening the religious, social base. Then, their movement after Indonesian independence was shown in the process of political participation and cooperation with the government or social, a political force for the struggle for freedom and the nation's development. Similarly, the followers' social base (disciples of the Sufi order) in the two periods of 20thcentury history was also changed. The changes that occurred in the period before independence more likely came from farmers' communities in the countryside, while the change after independence came from the urban communities. Thus, the role of tarekat is as crucial as the movements of Islamic renewal such as Sarekat Islam, Muhammadiyah, Unity of Islam and NahdlatulUlama ' $(\mathrm{NU}) .{ }^{18}$

${ }^{17}$ Sartono Kartodirdjo, Pemberontakan Petani Banten 1888: Kondisi, Jalan Peristiwa, Dan Kelanjutannya; Sebuah Studi Kasus Mengenai Gerakan Sosial Di Indonesia, terj. Hasan Basri dan Bur Rasuanto (Jakarta: Pustaka Jaya, 1984), 208.

${ }^{18}$ Dudung Abdurrahman, "Gerakan Sosial-Politik Kaum Tarekat Di Priangan Abad XX” (UIN Sunan Kalijaga Yogyakarta, 2008), 2-3. 
The Sufism of the tarekat based on the Sufi doctrine is outlined in the development of the teachings and ritual of mysticism that can grow and develop as a socio-political movement. This movement took place in the relationship between Sufism and the government of the ruling course or their involvement in the situation socio-political faced. The movements posed by the people in the congregation are continuously changing with the socio-political dynamics in Indonesia. However, the socio-political movement was also based on the change of Sufism to the development of sufi doctrine by modifying the movements of Sufism adjusted to the change of socio-political during the 20th century. Therefore, each Sufism grows and develops through religious roles over the spiritual and moral community that supported the difference in the behaviour of the socio-political relationship. The relation of Sufism with society and government always departs from the process of teacher-student interaction, developed in religious and socio-political movements. Communication is a concern for reciprocal relationships with governments, political parties, and mass organizations. ${ }^{19}$

The teacher-student relationship system in tarekat evolves from the ritual, educational, and da'wah activities. This religious activity serves as a media relationship socio-political. The socio-political role through the media goes as follows: First, the sufi order established social movement to preach political nationalism and anti-colonizers at the end of the Dutch colonial government and during the Japanese occupation. They became active in politics in an adversary process against the colonial government policies. The role of the Sufi order at this time gained public support because of its political action. The community made the tarekat as a ruhaniah road and murshid charismatic force moved a protector of the challenges of colonial government power. Secondly, the socio-political role of Sufi order through the media of the religious movement above survived during the independence of Indonesia. However, their socio-political relationship patterned reciprocal cooperation with the government, both the search process of national and state identity in the old order and the New Order's development process. The Sufi order developed an accommodating and participatory relationship with government politics. They always support legitimate countries throughout the

${ }^{19}$ Abdurrahman, "Gerakan Sosial-Politik", 266. 
government protecting and welfare of the community, especially Muslim society. Meanwhile, the socio-political ties between the Sufi orders and the socio-political forces took place in their support process independently of the political parties. In this case, the community of the Sufi order takes a different way depending on the political and the creation of the teacher's Sufi order (Murshid) in the groin to support a party. ${ }^{20}$

TQN also brings together three components of repentance: (1) An integral religious ideology, (2) The mechanisms of religious planthoppers in the community, and (3) dominant political power. The unification of these three components is seen from the pattern of the liquid charismatic, which is the most authoritative in the position of the most prevalent to the success of this traditional political program and movement because it is fluid control and controller of the system (tarekat). ${ }^{21}$

TQN became a Sufism movement in the nationalist frame. Where has an essential role in maintaining social-political stability in Indonesia? It is because the social and political aspects have a strong influence on safe absence. Safe means far from conflict, restrained, conducive, and comfortable in conducting activities. It is this key that the Sufi take precedence to contribute to maintaining socio-political stability. We can imagine how it would be if the socio-political state of a country is shaken (unstable) because of unmanagable conflicts. All aspects of the life of society will cease, which ultimately leads to the setbacks of a nation in all lines. Madharat (danger; calamity) generated by social instability is a strong factor for the sufi order to maintain socio-political stability. They see that security (stability) is the key in building all aspects of peoples ' lives and countries. Not only does it stop there, in terms of human beings will feel comfortable, solemn, and calm. The value of "safe" is a foundation for someone in doing various activities such as worship, social and other.

Sufism also plays an essential role in Islamization in the archipelago where Sufi Da'i brought Islam hundreds of years ago. Through Sufi order (tarekat), Islam's intellectual and rational spirit

${ }^{20}$ Abdurrahman, 266-268.

${ }^{21}$ Donald K. Eugene Smith, Agama Dan Modernisasi Politik (Jakarta: Rajawali Press, 1985), 85-86.; Thohir, Gerakan Politik Kaum Tarekat: Telaah Historis Gerakan Politik Antikolonialisme Tarekat Qadiriyah Wa Naqsyabandiyah Di Pulau Jawa, 152. 
enters the mind of Indonesian society. The acculturation or reciprocal relationship of Islamic teachings (Sufi order) with the local culture gave birth to the new intellectual and cultural manifestations that never existed before Islam came. However, Nurcholis Madjid, in this case, confirms that the elements of the local culture that can or should be used as the source of law are at least not contrary to the Islamic principles. Elements that contradict the tenets of Islam by themselves must be eliminated and replaced with something synergized with religion. ${ }^{22}$ The Sufi has a more compromising and compassionate attitude, so the indigenous people easily accept Sufism at the time. Even the inheritance of Hindu-Buddhist teachings, he said, has helped to expand the readiness of the Indonesian nation to recognize the arrival of Islamic religion through Sufism. In its development, Sufism has participated in the local mystical teachings. ${ }^{23}$

Nurcholis Madjid viewed this with the possibility of reciprocal acculturation between Sufism and local traditions or culture. The rules of the society in the past were overcome by practices contrary to the teachings of Tauhid and other teachings in Islam. For example, superstition and mythology, all of which must be eliminated and replaced with Islamic teachings that are relevant to the almighty or divine understanding. ${ }^{24}$ Thus, the presence of Sufism in Indonesia resulted in the reshuffle of the community or social transformation towards the better. However, at the same time, Sufism should not be ' disruptive ' or cut; A community tradition from its only time. ${ }^{25}$ However, it is more to ' compromise ' between local religions and cultures, looking for the theme's point so that it can synergize each other.

The cultural acculturation approach also helps the Sufi order be close to the people to facilitate the relationship between the local community and the Sufi order. These robust interlacing led them

${ }^{22}$ Nurcholis Madjid, Islam Doktrin dan Peradaban (Jakarta: Paramadina, 2008), 544.

${ }^{23}$ Nurcholis Madjid, Bilik-Bilik Pesantren: Sebuah Potret Perjalanan (Jakarta: Paramadina, 1997), 55; Abd. Moqsith Ghazali, "Corak Tasawuf Al Ghazali Dan Relevansinya Dalam Konteks Sekarang," Jurnal At-Tahrir: Jurnal Pemikiran Islam 13, no. 1 (2013): 61-85, https://doi.org/10.21154/al-tahrir.v13i1.7.

${ }^{24}$ Madjid, Islam Doktrin Dan Peradaban, 546.

${ }^{25}$ M. Leliyanto, "Kontekstualisasi Sufisme Dalam Kemodernan Dan KeIndonesiaan: Studi Atas Relevansi Pemikiran Sufisme Nurcholis Madjid Di Indonesia" (UIN Syarif Hidayatullah Jakarta, 2010), 64. 
to embrace Islam consciously easily, and this process gave birth to a mature closeness so that they could move together, unified to maintain the country's security and stability by actively committing resistance to the invaders. This is done by murshid TQN with its members.

In addition to the physical, political role against the invaders, TQN has also continued to develop its role and function after independence. As modeled by murshid TQN Abah Sepuh KH Abdullah Mubarrok immediately after the independence, precisely the old order era is a rebellion committed DI/TII. Thus, it is stirring the spirit of the Sufi people (Sufi order) to help the government, especially the Republican soldiers, in their fight. This was done by Abah Sepuh, which he arranged in his fate: "For the students and the Sufi order in Suryalaya environment to help Republican guerrillas in case of contact of weapons in the fight against the enemy." So, in this case, the tarekat became a government partner (Old Order) ${ }^{26}$ The Abah Sepuh action gives the gesture of the national spirit of a murshid which at that time has been supported by the connection of good relations with the national leaders. ${ }^{27}$ This is what makes the basis that the congregation participate in the real constriction in the dynamics of social politics and play an active role in safeguarding the nation's sovereignty.

Suryalaya, as the center of the dissemination of TQN (Qadiriyah wa Naqsyabandiyah) was used as one of the liaison posts of the TNI struggle officially formed on 03 June 1947 in the East-West Java area. Suryalaya is seen strategic because it is located in the middle of the regions ruled by the TNI. ${ }^{28}$ Murshid and ikhwan tarekat of TQN Suryalaya to the TNI and RI is seen from their attitude in the face of the movement DI/TII in West Java. This movement from the end of 1948 made R.I. as its political target. ${ }^{29}$ The role of Abah Sepuh was followed by his son Abah Anom which he got a will from his father to continue to help the TNI RI struggle. In his time, Suryalaya,

${ }^{26}$ Achmad Sanusi, "Abah Sepuh dan Pembentukan TQN PP. Suryalaya", dalam Nasution, Thariqah QadiriyahwaNasyabandiyah, 102.

${ }^{27}$ Abdurrahman and Nur, Sufisme Nusantara: Sejarah Pemikiran Dan Gerakan, $121-122$.

${ }^{28}$ Zainal Asikin, "Biografi Syaikh Abdullah Mubarrok bin Nur Muhammad (AbahSepuh)", dalam Dudung Abdurrahman, Sufisme Nusantara, 122.

${ }^{29}$ Pinardi, Sekarmadji Maridjan Kartosuwirjo (Jakarta: Aryaguna, 1964), 76. 
besides, was used as the headquarters of the TNI, also as a shelter for the people around. Abah Anom co-joined TQN to assist the TNI in fighting and counteracting the various terror and attacks (chaos) from the DI/TII. Therefore, his loyalty to the state and the TNI was regarded as a form of obedience and implementation of his father's "tanbih" ${ }^{30}$ Later, he gained many awards from the government. ${ }^{31}$

The potential of order is "sound warehouse." That potential has become the subject of widespread attention when Kiyai Musta'in Ramli, murshid tarekat Qadiriyah wa Naqsayabandiyah also then as the chairman of JATM (Jam'iyyah Ahli Thariqah Mu'tabarah) affiliated; expressed support of Golkar in the early decades of the 1970s. This statement caused reactance from other Kyais, which regarded him as a betrayal of NU in which at that time supported the PPP (Unity Development Party) and at the moment NU had not returned to Khitthah. Some of the badal khalifah moved to KH Adlan Aly Cukir Jombang, which later became the chairman of JATMAN (Jam'iyyah Ahli Thariqah al Muktabarah an Nahdliyah) as the "fraction" of JATMI's KH Musta'in, which led him to be fired from JATM's leadership. ${ }^{32}$

This becomes evidence that religious jam'iyah has a role and contribution in the political practice. Despite the turmoil that once befalls the "body" of Qadiriyah wa Naqsyabandiyah, then let us not judge the fortress Kyai Mustai'in "wrong" and the fort Kyai Adlan Aliy most "true." Perhaps at that time, Kyai Mustai' in has a separate consideration of why to direct the Jama'ah Tarekat (TQN) to the

${ }^{30}$ Tanbih of Abah Sepuh: 'obedience to the country' that makes Abah Anom demonstrate attitude and loyalty to the leadership of the state of Indonesia. Achmad Tafsir, Tasawuf Dalam Menuju Tuhan (Tasikmalaya: Latifah Press, 1995), 133.

${ }^{31}$ Djoehriyah Besman, Sinar Hate (Bandung: PD Kembang Sepat, t.t), 93-106. Here is the award obtained Abah Anom: Sign of award Kodam VI Siliwangi issued in Tasikmalaya August 17, 1956, Letter of Love by Kodam VI Siliwangi in Rajapolah on September 17, 1961, the award from Mount Djati Batalion 329 for his contribution to regional security in 1962, the mark of the board of Directors of P.N. Tjabang Djawa Barat on 24 September 1963, Charter of the Governor of the regional head of Djawa Barat on 20 May 1965 and many more. Abdurrahman, Sufisme Nusantara,124-125.

32 Bruinessen, Tarekat Naqsyabandiyah Di Indonesia, 178-180; Rif'i, Filsafat Tasawuf, 252. Aziz, Risalah Memahami Ilmu Tasawuf, 59-62; Sukamto, Kepemimpinan Kiai Dalam Pesantren (Jakarta: LP3ES, 1999), 185-206; Abdullah Mubarok, "Pelaksanaan Tawajjuhan Pada Thariqah Qadiriyah Wa Naqsyabandiyah an Nahdliyah Di Pesantren Futuhiyah Suburan Mranggeng Demak" (Fakultas Ushuluddin IAIN Walisongo Semarang, 1982), 61; . 
Golkar Party. And it is proven, with the existence of Khittah NU, which states out of the practical political world that pioneered $\mathrm{KH}$. Achmad Siddiq, so that residents NU and Kiyai NU even Murshid is not obliged to be anchored to PPP, precisely when PKB was born, so the NU Group split, there is to PPP, and there is also to the PKB. ${ }^{3334}$

Kyai Musta'in movement was no more wrong and distorted. On the one hand, he also a citizen who has the right to determine his political choice. And according to the constitutional view, it is legitimate as a form democratic aspiration. However, it poses controversy in the internal TQN. The authors view that we should not accuse the stronghold of the A's and the most dedicated stronghold $\mathrm{B}$. What needs to be emphasized is the role and strategy of the order in the politically practical world. Kyai Musta'in was not the first teacher to play his political position, where earlier in the early days of independence, Shaykh Haji Jalaluddin Bukit Tinggi established the Political Party Thariqah Islam (PPTI). The teacher of Naqsayabandiyah was previously a member of Perti but left the party because of the conflict with Shaykh Sulaiman al-Rasuli. ${ }^{35}$ This is the form of existence in the political world of national politics that can be said to have sympathy for the political development in the archipelago, not a Sufi self-imposed and does not interfere with the development and stability of homeland politics. This is what we ought to appreciate, given the role of the order and the murshid teacherstudents are so important for the nation of Indonesia's stability and unity.

Nationalism modeled by the murshids and members of the TQN shows a sense of unity among one another, eliminating the sense of distinction between both religions and others, and uniting to defend and protect the country from various disorders threatening the

${ }^{33}$ Ja'far Shodiq, Pertemuan Antara Tarekat Dan NU (Yogyakarta: Pustaka Pelajar, 2008), 208-209. It can be interpreted that KH Musta'in Ramli's move precedes the era of the sharpness of seeing the signs of the times. And it can also be said as the " reference " ofNU in his "Khitthah" which is no longer a political party, supporters of practical political party and liberates its citizens to channel its political aspirations into all the parties that exist at the time and that is according to his conscience.

${ }^{34}$ Endang Turmudi, "The Tarekat Qadiriyah Wa Naqsyabandiyah in East Java and Islamic Politics in Indonesia," Asian Journal of Social Science 26, no. 2 (1998): 84-85, https://doi.org/10.1163/030382498X00166.

${ }_{35}$ Werner Kraus, Islamische Mystische Bruderschaften Im Heutigen Indonesien (Hamburg: Institut fur Asienkunde, 1990), 91-100. 
sovereignty of the country. Without unity, it can be tricky, even to be impossible, to protect the country from problems. It is a proof that the enormous benefits of unity, preferably in the division of many dangers that can destroy all the alone of religious life, national, society and state. ${ }^{36}$ Unity became a fundamental cornerstone for the realization of love for homeland and unity also reduced divisions, hostility and strife. Thus, it will be maintained balance, togetherness, harmony and prosperity during community life. The explanation is the basis to officially develop the teachings of the order that does not only focus on the problem of religious rituals, but also flourish nationalism for a vision of the mission of peace, security, welfare and unity decorated with moderate attitudes, tolerance, loving; affectionate, balanced, and nationalist. ${ }^{37}$

\section{PROCESS OF REVITALIZING NATIONAL POLITICAL VALUES OF QADIRIYAH WA NAQSYABANDIYAH}

In theory, national political values can be associated with the problem of nationalism. The order has always had a tendency to dialectics with the evolving socio-political realities. If boarding schools are referred to as subcultures, then the order as a teaching as well as a religious transmission network that has formed a distinct political power religious character. This character is formed based on an affirmative political culture that accomodates political reality, then a critical political culture to the political system and power. ${ }^{38}$ The critical tendency towards the political system and power can be seen in the Sufism phenomena and order that collaborates with power,

${ }^{36}$ Tim Bahstsul Masail HIMASAL, Fiqih Kebangsaan; Merajut Kebersamaan Di Tengah Kebhinnekaan (Kediri: Lirboyo Press dan LTN Himasal Pusat, 2018), 7.

${ }^{37}$ Sulaiman Sulaiman, "Perubahan Sosial Berbasis Tasawuf: Studi Kasus Fethullah Gülen Dan Gülen Movement," Al-Tahrir: Jurnal Pemikiran Islam 16, no. 1 (June 24, 2016): 21-46, https://doi.org/10.21154/al-tahrir.v16i1.359; Said Aqil Siradj, "Tasawuf Sebagai Basis Tasamuh," Jurnal At-Tahrir: Jurnal Pemikiran Islam 13, no. 1 (2013): 87-106, https://doi.org/10.21154/al-tahrir.v13i1.8; Akhiyat Akhiyat, "Islam Nusantara Antara Ortodoksi Dan Heterodoksi," Al-Tahrir: Jurnal Pemikiran Islam 17, no. 1 (May 28, 2017):247-68, https://doi.org/10.21154/altahrir.v17i1.881; Muhammad Itsbatul Haq, "Tasawwuf (Sufism) as The Basis for Internalizing Humanist Character of Indonesian Muslims (Case Study of Pesantren in Yogyakarta and Madura)," Sunan Kalijaga: International Journal of Islamic Civilization 2, no. 2 (September 30, 2019): 235-62, https://doi.org/10.14421/skijic.v2i2.1514.

${ }^{38}$ Jamil, Tarekat dan Dinamika Sosial Politik, 12. See also John Brenkman, Culture and Domination (Ithaca: Cornel University Press, 1987). 
even being an instrument of religious legitimacy for the prevailing political system and power. Such affirmative political culture and critical political culture are determined by their commitment to power on the one hand and their relationship to the people on the other. ${ }^{39}$ It is through this concept that the Qadiriyahwa Naqsyabandiyah order transmits the concept of national political values. In the process of revitalizing the national political values of the Qadiriyah wa Naqsyabandiyah order can be seen from several steps:

First, through the role of elite order (mursyid TQN). The elites of the order as a symbol of respect for the members of the order as well as the wider community have an important role in encouraging, stimulating, and mobilizing their followers to be actively involved in national issues. The relationship of the elite order (TQN) with the rulers provides alternative solutions to the interests of the nation and the state and also becomes an example to the people that the interests of the country are also important in addition to religious interests. ${ }^{40}$ The political struggle of the order is all about the mursyid's own position as a religious figure, worshippers, and also a spiritual teacher whose all-say is embraced by his followers. Thus, it is natural that the order is very close to the political issues. ${ }^{41}$

Second, through the religio political system. The Qadiriyah wa Naqsyabandiyah order has a religio-political system which means also taking into account and managing issues related to national politics built on the structure or values of Islam in its teachings. The ideological component of the system is almost entirely sourced or endorsed by religion. Besides, there is also the legitimacy of leaders based on religious ideas to force themselves to uphold maximum community stability to achieve specific goals. ${ }^{42}$

39 Jamil, 12.

${ }^{40}$ Mahmud Sujuthi, Politik Tarekat Qadiriyah wa Naqsyabandiyah Jomban: Studi tentang hubungan agama, negara dan masyarakat (Yogyakarata: Galang Press, 2001). See Parson's theory in K.J. Veeger, Realitas Sosial (Jakarta: Gramedia, 1993), $192 \& 214$.

${ }^{41}$ Ziadi, "Tarekat dan Politik, Living Islam, Vol. 1, No. 2 (2018), 249.

${ }^{42}$ Ajid Thohir, Gerakan Politik Kaum Tarekat: Telaah Historis Gerakan Politik Anti kolonialisme Tarekat Qadiriyah wa Naqsyabandiyah di Pulau Jawa, 148; Kartodirjo, Pemberontakan Petani di Banten 1888, 257-291.; Imam Kanafi, "Tarekat Kebangsaan: Kajian Antropologi Sufi Terhadap Pemikiran Nasionalisme Habib Lutfie", Jurnal Penelitian, Vol. 10, No. 2 (November 2013), 336-358. 
Third, relations with political parties. Qadiriyah wa Naqsyabandiyah order since the old order has established relations with political parties as a form of establishing good relations with the ruler through political parties to provide advice, suggestions and solutions. Their role after independence was to draw closer to the rulers and elites of political parties as a means of keeping the nation in control of this country on the line of truth. ${ }^{43}$ The success of the elite in fighting alongside the police elite, such as Abah Anom Suryalaya and Kyai Mustain Ramli, succeeded in smoothing the movement of the organization in response to the issues of modernization and development of the Islamic educational institutions. ${ }^{44}$

Fourth, through the synergy between the encouragement of Islamic teachings, the motivations of individuals and groups, and interaction with the outside world (purification movements and dealing with colonialism). The encouragement of Islamic teachings that focused on maintaining unity, sovereignty and amar ma'ruf nahi mungkar became a spirit of its own for the order. Then, the motivation of individuals and groups in spreading the teachings of the order to remain exists which is supported by interaction with the outside world, namely efforts to purify the teachings of the order from the distorted doctrine and resistance of the order against the invaders. ${ }^{45}$ Through the formation of these patterns, the Qadiriyah wa Naqsyabandiyah order succeeded in instilling national political values and social ethics into its members.

Fifth, through the functioning of the order as a religious and social institution. According to Martin Van Bruinessen, the order does not only have a religious function. Each order, according to him, is a kind of large family whose members consider themselves brothers to each other. The function of a religious order and such social functions evolve into political power. As it has been mentioned that many sheikhs are charismatic because of their many followers, and great influence, the sheikhs play an important role in the sociopolitical dynamics. Thus, the governments or rulers normally see

\footnotetext{
${ }^{43}$ Abdurrahman \& Nur, Sufisme Nusantara,132-136.

${ }^{44}$ Ja'far Shodiq, Pertemuan Antara Tarekat \& NU, 26.

${ }^{45}$ Jamil, Tarekat dan Dinamika SosialPolitik,85-88.
} 
these sheikhs as a threat or as useful allies, making it impossible to ignore them. ${ }^{46}$

In this case, it can be said that the order besides having spiritual potential; religious, it also has social, economic, artistic potential. Thus, it is natural if the order has a strategic position in politics. That potential and strategic position will always be contextually meaningful in people's lives. Then, religiously, it became a kind of vehicle for the planting and transmission of religious values during society. Here the order has ethics and spiritual contribution during national discourse coloured with various social, political, and economic problems. Meanwhile, institutionally the order becomes a vehicle of articulation of social interests. That eventually became a network of religious, social movements. ${ }^{47}$

Thus, through the measures above the process of revitalizing the national political values of the Qadiriyah wa Naqsyabandiyah order can be instilled in its members as well as the broader community to built peaceful society while making the effort of being a righteous servant of God. Vertical righteousness alone is not enough; it takes righteousness horizontally as a counterbalance. Finally, life will run harmoniously, intact, and continuously.

\section{CONCLUSION}

Qadiriyah wa Naqsyabandiyah has played a social, political role to help people and Indonesians come out of adversity, suffering and misery due to colonization. Due to the small impact of the jam 'iyah as socio-religious organization, it expands to the political-religious aspect. Synergize worldly interests; against the invaders in the importance of $u k h r a w i$; worship. This synergy delivers a balanced, harmonious, moderate, and proportionistic life pattern. Then, the process of revitalizing the national political values of the Qadiriyah wa Naqsyabandiyah order can be seen from several steps: (1) through the role of the elite order (mursyid TQN), (2) through the religio-political system, (3) relations with the political parties, (4)

${ }^{46}$ Martin Van Bruinessen, NU: Tradisi, Relasi-relasi Kuasa Pencarian Wacana Baru (Yogyakarta: LKiS, 1994), 3-4.; Amir Maliki Abitolkha \& Muhamad Basyrul Muvid, Melacak Tarekat-tarekat Muktabar di Nusantara (Kuningan: Goresan Pena, 2020), 7 .

${ }^{47}$ Jamil, Tarekat dan Dinamika Sosial Politik,43. 
through synergy between the encouragement of Islamic teachings, the motivation of individuals and groups, and interaction with the outside world, and (5) through the function of the order as a religious and social institution. This article recommends further research to investigate the relationship of rulers with the TQN Murshid in the historical study of the colonial period to post-reform.

\section{REFERENCES}

Abdurrahman, Dudung. "Diversity of Tarekat Communities and Social Changes in Indonesian History."Sunan Kalijaga: International Journal of Islamic Civitization 1, no. 1 (2018): 6192. https://doi.org/https://doi.org/10.14421/skijic.v1i1.1217.

_. "Gerakan Sosial-Politik Kaum Tarekat Di Priangan Abad XX.” UIN Sunan Kalijaga Yogyakarta, 2008.

Abdurrahman, Dudung, and Syaifan Nur. Sufisme Nusantara: Sejarah Pemikiran Dan Gerakan. Yogyakarta: Ombak, 2019.

Abdurrahman. "Fenomena Kyai dalam Dinamika Politik: Antara Gerakan Moral dan Politik". Jurnal KARSA. Vol. XV. No. 1 (April 2009): 28.

Abitolkha, Amir Maliki \& Muhamad Basyrul Muvid, Melacak Tarekat-tarekat Muktabar di Nusantara. Kuningan: Goresan Pena, 2020.

Akhiyat, Akhiyat. "Islam Nusantara Antara Ortodoksi Dan Heterodoksi." Al-Tahrir: Jurnal Pemikiran Islam 17, no. 1 (May 28, 2017): 247. https://doi.org/10.21154/altahrir.v17i1.881.

Al-Abza, M. Thohar et.al. "Power Relation Between Tarekat Qadiriyah wa Naqsyabandiyah (Tarekat Cukir) and Partai Persatuan Pembangunan (PPP) in Jombang, East Java". Episteme, Vol. 14. No. 2 (Desember 2019): 286.

Al-Wakil, Abdurrahman. Hadhihi Hiya al-Shufiyyah. Beirut: Daar al-Kutub al-Ilmiyah, 1984.

Andalusi, Abu Hayyan al. Tafsir al-Bahr al-Muhit. Jilid 4. Beirut:

Dar al Kutub al Ilmiyah, 2002. 
Aqib, Kharisuddin. Al-Hikmah: Memahami Teosofi Tarekat Qadiriyah wa Naqsyabandiyah. Surabaya: Bina Ilmu, 2012.

Bruinessen, and Howell. Sufisme and the 'Modern' in Islam. New York: I.B. Tauris \& Co. Ltd, 2007.

Bruinessen, Martin Van. Kitab Kuning, Pesantren Dan Tarekat. Bandung: Mizan Pustaka, 1995.

Bruinessen, Martin Van.NU: Tradisi, Relasi-relasi Kuasa Pencarian Wacana Baru. Yogyakarta: LKiS, 1994.

. Tarekat Naqsyabandiyah Di Indonesia. Bandung: Mizan Pustaka, 1992.

Dhofier, Zamakhsyari. Tradisi Pesantren: Studi Tentang Pandangan Hidup Kiyai. Jakarta: LP3ES, 1984.

Evan-Pritchard, E.E. The Sanusi of Cyrenaica. London: Oxford University Press, 1949.

Fuhaidah, Ulya. "Tariqa and Philantrophy: The Studi of Tariqa Qadiriyah Naqsyabandiyah Movement in Kuala Tungkal, Jambi." Insaniyat: Journal of Islam and Humanities 3, no. 1 (2018): 29-46. https://doi.org/10.15408/insaniyat.v3i1.7509.

Ghazali, Abd. Moqsith. "Corak Tasawuf Al Ghazali Dan Relevansinya Dalam Konteks Sekarang." Jurnal At-Tahrir: Jurnal Pemikiran Islam 13, no. 1 (2013): 61-85. https://doi. org/10.21154/al-tahrir.v13i1.7.

Hamidah, Hamidah. "Gerakan Petani Banten: Studi Tentang Konfigurasi Sufisme Awal Abad Xix.” Ulumuna 14, no. 2 (November 5, 2017): 323-240. https://doi.org/10.20414/ujis. v14i2.220.

Haq, Muhammad Itsbatul. "Tasawwuf (Sufism) as The Basis for Internalizing Humanist Character of Indonesian Muslims (Case Study of Pesantren in Yogyakarta and Madura)." Sunan Kalijaga: International Journal of Islamic Civilization 2, no. 2 (September 30, 2019): 235. https://doi.org/10.14421/skijic. v2i2.1514. 
HIMASAL, Tim Bahstsul Masail. Fiqih Kebangsaan; Merajut Kebersamaan Di Tengah Kebhinnekaan. Kediri: Lirboyo Press dan LTN Himasal Pusat, 2018.

Huda, Sokhi. "Karakter Historis Sufisme: Masa Klasik, Modern Dan Kontemporer." Teosofi: Jurnal Tasawuf Dan Pemikiran Islam 7, no. 1 (2017). https://doi.org/https://doi.org/10.15642/ teosofi.2017.7.1.30-63.

Ja'far. "Tarekat Dan Gerakan Sosial Keagamaan Syakh Hasan Maksum." Teosofi: Jurnal Tasawuf Dan Pemikiran Islam 5, no. 2 (2015): 269-93. https://doi.org/https://doi.org/10.15642/ teosofi.2015.5.2.269-293.

Jamil, Muhsin. Tarekat Dan Dinamika Sosial Politik. Yogyakarta: Pustaka Pelajar, 2005.

Kartodirdjo, Sartono. Pemberontakan Petani Banten 1888: Kondisi, Jalan Peristiwa, Dan Kelanjutannya; Sebuah Studi Kasus Mengenai Gerakan Sosial Di Indonesia. Jakarta: Pustaka Jaya, 1984.

Kartodirejo, Sartono. The Peason Revolt of Banten in 1888. 'S Gravenhage: Nijhoff, 1966.

Khanafie, Imam. "Tarekat Kebangsaan Habib Lutfi Bin Yahya; Pemikiran Dan Praktik Nasionlisme.” Jurnal Penelitian 10, no. 2 (2013): 353-54.

Kraus, Werner. Islamische Mystische Bruderschaften Im Heutigen Indonesien. Hamburg: Institut fur Asienkunde, 1990.

Leliyanto, M. "Kontekstualisasi Sufisme Dalam Kemodernan Dan KeIndonesiaan: Studi Atas Relevansi Pemikiran Sufisme Nurcholis Madjid Di Indonesia." UIN Syarif Hidayatullah Jakarta, 2010.

Madjid, Nurcholis. Bilik-Bilik Pesantren: Sebuah Potret Perjalanan. Jakarta: Paramadina, 1997.

Islam Doktrin Dan Peradaban. Jakarta: Paramadina, 2008.

Mashar, Ali. "Genealogi Dan Penyebaran Thariqah Qadiriyah Wa Naqshabandiyah Di Jawa.” Al-A 'raf: Jurnal Pemikiran Islam 
Dan Filsafat 13, no. 2 (2016): 233-62. https://doi.org/10.22515/ ajpif.v13i2.75.

Moesa, Ali Maschan. "Kiyai Berpolitik Tidak Dilarang”, dalam Aula. No. 03. Maret 2007.

Mubarok, Abdullah. "Pelaksanaan Tawajjuhan Pada Thariqah Qadiriyah wa Naqsyabandiyah an Nahdliyah Di Pesantren Futuhiyah Suburan Mranggeng Demak.” Fakultas Ushuluddin IAIN Walisongo Semarang, 1982.

Mu'min, Ma'mun. "Pergumulan Tarekat dan Politik: Peranan Kiyai Haji Muhammad Shiddiq dalam Tarekat dan Politik di Kudus". Fikrah, Vol. 2. No. 1 (Juni 20014): 176-177.

Muvid, Muhammad Basyrul. "Nilai-Nilai Pendidikan Karakter Dalam Praktik Tarekat Qadiriyah Wa Naqsyabandiyah Di Pondok Pesantren Al Ittihad Tawangsari Trowulan Mojokerto." UIN Sunan Ampel Surabaya, 2015.

Muvid, Muhammad Basyrul, and Nur Kholis. "Konsep Tarekat Sammaniyah Dan Peranannya Terhadap Pembentukan Moral, Spiritual Dan Sosial Masyrakat Post Modern." Dialogia: Jurnal Studi Islam Dan Sosial 18, no. 1 (2020): 79-99. https:// doi.org/10.21154/dialogia.v18i1.2038.

Nasir, Rabi'ah, and Arsheed Ahmad Malik. "Role and Importance of Sufism in Modern World."International Journal of Advancements in Research and Technology 2, no. 1 (2013).

Nasution, Harun. Tarekat Qadiriyah Wa Naqsyabandiyah. Tasikmalaya: IAILM, 1990.

Nasution, Syawaluddin. "Negara Dan Nasionalisme Dalam Pandangan Kaum Tarekat (Studi Terhadap Tarekat Naqsyabandiyah Khalidiyah Babussalam)." Universitas Islam Negeri Sumatera Utara, 2018.

Nawawi, Ismail. Tarekat Qadiriyah Wa Naqsyabandiyah. Surabaya: Karya Agung, 2008.

Pinardi. Sekarmadji Maridjan Kartosuwirjo. Jakarta: Aryaguna, 1964. 
Qudus, Abdul, and Lalu Muhammad Ariadi. “Gerakan Tarekat Dan Pertumbuhan Budaya Berfolosofi Di Lombok.” Teosofi: Jurnal Tasawuf Dan Pemikiran Islam 5, no. 2 (2015): 321-45. https:// doi.org/https://doi.org/10.15642/teosofi.2015.5.2.321-345.

Ritzer, George, and Douglas J. Goodman. Teori Sosilogi Modern. Jakarta: Prenada Media, 2005.

Riyadi, Agus. "Tarekat Sebagai Organisasi Tasawuf." Jurnal at Taqaddum 6, no. 2 (2014): 361.

Shodiq, Ja'far. Pertemuan Antara Tarekat Dan NU. Yogyakarta: Pustaka Pelajar, 2008.

Siddiq, Achmad. Khittah Nahdliyyah. Surabaya: Balai Buku, 1980.

Siradj, Said Aqil. "Tasawuf Sebagai Basis Tasamuh.” Jurnal AtTahrir: Jurnal Pemikiran Islam 13, no. 1 (2013): 87-106. https://doi.org/10.21154/al-tahrir.v13i1.8.

Smith, Donald K. Eugene. Agama Dan Modernisasi Politik. Jakarta: Rajawali Press, 1985.

Stange, Paul. "The Sumarah Movement in Javanesa Mysticism." University Wiconsin-Madison, 1980.

Sujuthi, Mahmud. Politik Tarekat Qadiriyah wa Naqsyabandiyah Jombang: Studi tentang hubungan agama, negara dan masyarakat. Yogyakarata: Galang Press, 2001.

Sukamto. Kepemimpinan Kiai Dalam Pesantren. Jakarta: LP3ES, 1999.

Sulaiman, Sulaiman. "Perubahan Sosial Berbasis Tasawuf: Studi Kasus Fethullah Gülen Dan Gülen Movement." Al-Tahrir: Jurnal Pemikiran Islam 16, no. 1 (June 24, 2016): 21. https:// doi.org/10.21154/al-tahrir.v16i1.359.

Tafsir, Achmad. Tasawuf Dalam Menuju Tuhan. Tasikmalaya: Latifah Press, 1995.

Thohir, Aji. Gerakan Politik Kaum Tarekat: Telaah Historis Gerakan Politik Antikolonialisme Tarekat Qadiriyah Wa Naqsyabandiyah Di Pulau Jawa. Bandung: Pustaka Hidayah, 2002. 
Trimingham, J. Spencer. The Sufi Order in Islami. New York: Oxford University Press, 1973.

Turmudi, Endang. "The Tarekat Qadiriyah Wa Naqsyabandiyah in East Java and Islamic Politics in Indonesia."Asian Journal of Social Science 26, no. 2 (1998): 65-84. https://doi. org/10.1163/030382498X00166.

Verger, K.J. Realitas Sosial. Jakarta: Gramedia, 1986.

Ziadeh, Nicola A and Sanusiyah. A Studi of a Revivalist Movement in Islam. Leiden: Brill, 1958. 